\title{
Research on the Employment-oriented College English Teaching Reform in Medical Colleges*
}

\author{
Yuefang Sun \\ School of Foreign Languages, Jining Medical University, Jining, Shandong Province, China
}

\begin{abstract}
In order to meet the increasing demand of our society for inter-disciplinary talents (people who have got training in more than one professional field and do excellent in them), English teaching activities of medical schools in China should be employment-oriented, and the new teaching method should be found out to achieve the goal of talent training. Guided by the concept of employment-oriented education and after analyzing the problems existing in present college English teaching, this essay did a research on the reform of the employment-oriented college English teaching in medical colleges and universities.
\end{abstract}

Index Terms - employment-oriented, college English, teaching reform

\section{INTRODUCTION}

There has been the problem that teaching and practice in most colleges and universities of our country can't meet the social demand for inter-disciplinary talents. As a result, in recent years millions of college students graduated form colleges or universities, but seldom can find the job that matches his or her own specialized field. Consequently, many graduates are between jobs or losing their jobs, which definitely results into the waste of education resources in colleges and universities and made a great difference to social stability and development.

Due to the increasing international communication and cooperation, there are more and more transnational medical activities, so the demand of our society for medical talents is stronger. English is not only a subject among humanities but also an instrumental discipline, which makes English be one of the most important conditions to judge whether a medical talent qualified or not according to his or her English level (Luo Huan, 2013).

The talent training goal of colleges and universities should keep in pace with our society in order to meet its demand for inter-disciplinary talents. The so-called "inter-disciplinary talents", also well known as well-rounded talents, refers to people who not only own professional competence but also master English knowledge very well. Due to their stronger competence, higher caliber and profounder knowledge, this kind of people can be competent in many fields

\section{The Analysis of the CuRRent Situation of GRaduates’ Employment and Its Reasons}

The employment of graduates has been a hot issue, a pressing issue. According to the data of the rate of employment released online, despite a rally in 2010 , the employment of graduates has been trending down over the past decade, and there are serious contradictions between the supply and demand of qualified graduates. While the need for applied talents has strongly changed, the setup of college curriculums and the goal of talent training remain the same. High-skilled individuals are sought after in job market, but graduates usually can't meet the demand of our society, which end up with an increasing employment pressure year by year. There are many factors causing this phenomenon, which can be summarized mainly into three aspects: the setup of college courses, the socioeconomic structure, and the self-awareness and the career planning of graduates.

1. The same arrangement of college courses doesn't accord with social industrial structure, so college education can hardly reach the expected effect. Only when the structure of college courses is highly consistent with that of industry, can a higher employment rate be achieved. College courses feature basic courses which are really important in education, but there is always a disconnection between theory and practice. Only when they are arranged to learn courses needed by our society and given more opportunities to practice what they've learned, can graduates adjust to the society as soon as possible.

2. As to the socioeconomic structure, social demands have changed with the changes of industrial structure, and these changes definitely will cause people to change their original jobs who will become competitors of graduates, which makes job hunting become more difficult. Our society is hungry for people with high skills, which in part comes from experiences, so graduates with few practical experiences besides few-month internship seems to be inferior to people with more experiences in job market.

3. The self-awareness of graduates is important, too. After graduating from colleges, with a bachelor or master degree, many graduates are always deeply disappointed due to their too high expectation of jobs. Universities and colleges should guide students evaluate themselves correctly, help them make a proper career plan, and offer necessary

\footnotetext{
* Supporting Fund for Teachers' research of Jining Medical University (JYFC2019RW006)
} 
psychological counseling when they suffer psychological trauma. Only with the correct self-evaluation and excellent psychological quality as well as a proper career plan, can graduates correctly analyze their pros and cons in job market and find a proper job.

\section{InVestigation into College English Reform in Medical Schools And the Present Learning Status Quo OF MEDICAL MAJORS}

College English is anything but a core curriculum in medical college, not so important as medical curriculums, so English teaching has not been given enough attention to in terms of distributing periods and introducing qualified personnel. As a result, there is always a lack of English teachers, and a small number of English teachers have to finish all the teaching tasks. In order to finish the tough teaching tasks in the limited periods, teachers have to adopt the so-called "forced-feeding methods of teaching". Though teachers work hard in class, most teaching jobs are low effective or even ineffective due to the dull teaching method.

With busy medical learning tasks and dull English learning, students' enthusiasm for English is fading away. The only motivation to learn English is to pass CET4 and get the diploma, which can help them graduate smoothly. Though most students can pass CET4, even with high marks, and though they can makes complicated sentences with a big vocabulary of words in the exam, they can not write correct medical records when working in the hospital, neither can they communicate with people in English properly, which are all due to the fact that what they have learned in schools has nothing to do with their career. So it's necessary and urgent to carry on the employment-oriented college English teaching reform.

\section{THE EMPIRICAL RESEARCH ON THE EMPLOYMENT-ORIENTED COLLEGE ENGLISH REFORM IN MEDICAL SCHOOL}

The so-called "employment-orientation" thought refers to the educational opinion that education should eventually meet the professional demand, aiming at provide talents with sustainable development for society (Shu Na, 2016). Simply speaking, one of the goals of college teaching and practice should be to develop students' professional competence by adding career awareness, ambitions, values, ethics, code, and quality to professional teaching system, so that graduates can find proper jobs in job markets and can make greater social contribution.

\section{Research Objective}

This research aims at expounding and proving the feasibility and effectiveness of college English teaching method oriented to employment in medical college.

2. Research Objects

This teaching experiment carried on by selecting randomly four classes of Nursing majors of Grade 2017 in Jining Medical University as the research objects. Then they were divided into two groups: control group (about 97 students of Class One and Class Two) and experimental group (about 98 students of Class three and Class Four) .

3. Research Instruments

The research instruments included questionnaire, classroom observation, two sets of College Test Papers and follow-up survey. The content of questionnaire is about the motivation of students for English learning, which is composed of three parts with 12 questions: future development tool, internal interest, and external environment. Before released, the questionnaire had been tested, the result of which showed that it was of high reliability and high degree. A total of 195 questionnaires were distributed among nursing majors of two groups, and 193 questionnaires were taken back on the spot: 190 valid questionnaires and 3 invalid. The data was statistically analyzed with the software SPSS11.0 (Liao Youguo, 2011).

4. The Result and Analysis of the Questionnaire

According to statistics online, there is a serious disproportion of doctors and nurses, as a result of which talents majoring in nursing are urgently needed. So in medical colleges and universities, compared with clinical majors, nursing majors is much easier to find a job after graduation, which results into the phenomenon that most of the students learn English only for the purpose of employment after graduation.

From table I, it can be easily seen that the motivations for learning college English of nursing majors, who have been chosen to take part in the questionnaire, have been listed in descending order of importance as follows: an useful tool to look for jobs, external factors, personal interests. All in all, being a useful tool to look for jobs is the first reason for most of the students to learn college English, while few students learn English just for internal interest. So to the students majoring in nursing of Jining Medical University, instrumental motivation sits at the top. Students also pay more attention to objective factors, such as network environment, the competence of their English teacher, the quality of textbook, etc, which reflects that the motivations of students for learning English will be greatly affected by these objective factors. In a sense, personal motivations for learning are decided by the socio-cultural factors, which reflect the demands of our society (Cai Hong, 2019). Consequently, the reform of college English teaching mode should be launched based on the practical demand of our society for talents with excellent English. 
TABLE I

THE MOTIVATIONS AFFECTING MEDICAL MAJORS' ENGLISH LEARNING

\begin{tabular}{|l|l|l|l|}
\hline Dimensions & Contents & No & PCT \\
\hline \multirow{5}{*}{ An Useful Tool } & Great strength in job-hunting & 121 & $63.7 \%$ \\
\cline { 2 - 4 } & Sense of fulfillment given by mastering English & 6 & $3.2 \%$ \\
\cline { 2 - 4 } & Demand for going abroad & 10 & $5.3 \%$ \\
\cline { 2 - 4 } & Demand for pursuing a further study & 6 & $3.2 \%$ \\
\cline { 2 - 4 } & Ability of communicating with foreigners & 7 & $3.7 \%$ \\
\hline \multirow{5}{*}{ Personal interests } & Interest in foreign culture & 1 & $0.5 \%$ \\
\cline { 2 - 4 } & Interest in English language & 1 & $0.5 \%$ \\
\cline { 2 - 4 } & Love for English songs and movies & 7 & $3.7 \%$ \\
\hline \multirow{5}{*}{ External factors } & High learning efficiency due to the Internet & 8 & $4.2 \%$ \\
\cline { 2 - 4 } & Orders from parents & 1 & $0.5 \%$ \\
\cline { 2 - 4 } & A good English teacher & 12 & $6.3 \%$ \\
\cline { 2 - 4 } & The interesting class activities & 10 & $5.2 \%$ \\
\hline
\end{tabular}

\section{EMPLOYMENT-ORIENTED REFORMS ON COLLEGE ENGLISH TEACHING}

\section{A. The Rudimental Circumstances}

As an in-service English teacher with 15years' teaching experience, the author has done the employment-oriented teaching reform in two experimental classes, while going on the traditional teaching mode in the other two control classes. The author has tested two groups before and after reform respectively with the same test paper and the same length of time. The results of these tests can be seen from Table II and Table III. Moreover, the author did some follow-up investigations into college English learning engagement in the subsequent two semesters, the result of which can be seen in Table IV.

\section{B. The Implementation of Employment-oriented Teaching Reform}

\section{To update English curriculum}

College English used to focus on basic English with less professional English. It seems that the reason students pay little attention to college English is that it has little to do with their future career. Students learn it only to pass the exam. Thus, English curriculums should be set up according to students' learning abilities and their demands for jobs, that's, on the one hand, set up a reasonable curriculum, especially hours of practical courses, which can enable students to have enough time to practice what they have learned. On the other hand, add more contents relevant to their future career, such as translation, resume writing, interview, etc, to enhance their competition in job hunting.

2. At the beginning of the first semester, teachers of college should organize an English test for freshmen to know about the specific English level of them, and according to the result, students will be divided into different classes with different teaching methods, students with the same or familiar level in the same class, and teachers ranked will finish the relevant teaching tasks. The arrangements of teaching plan, preparation, teaching process, teaching pace, and even the form of evaluation differ between different classes with different levels, which enables teachers can teach students in accordance with their aptitude, so-called "the layered teaching method". There is no need to worry about the negative effect on their psychological well-being, because as undergraduates, their main concern is to find an ideal job after graduation. What's more, the layered teaching method can arouse their interest of learning English and motivate them to update their level by achieving their learning target in the present class.

3. To innovate teaching method and improve teaching efficiency. Setting up proper teaching mode primarily oriented towards employment is key to improve teaching efficiency and effectiveness. One the one hand, teachers should treat college English as the main tool to improve students' professional demeanor so as to narrow the gap between students' professional qualities in English and the demand of society; On the other hand, apart from basic English teaching, teachers are supposed to pay more attention to improving students' competence in solving problems. So teachers are expected to adopt situational language teaching method to construct the atmosphere of English teaching and learning circumstance. Situational Language Teaching Method is a way to activate the teaching of language knowledge through the design of authentic and concrete situation (Juan Du, 2017). Through the simulated employment situation, students can be aware of their abilities in solving problems, and then they can make themselves more competent in the future study. Teachers should optimize English learning objectives for students according to their job orientation to enhance their internal motivation for English learning. When it comes to medical majors, teachers should pay more attention to the interaction and integration of multi subjects, guide students to learn English from the standpoint of career planning.

4. To create more opportunities for students' internship. As for the nursing majors, they should be given more chances to go on a field trip to a hospital. Through the internship, not only should they learn how to cooperate with coworkers, but also they have to practice communicating with patients properly in English. In that case, they will have a good command of English language skill.

5. To build up the ranks of teachers and raise their professional ethics and competence. The construction of teaching staff is a critical factor in improving college English teaching efficiency.

First, colleges should find out more ways to attract more talents to join their team to improve the all-round quality of 
the teaching staff and optimize teaching structure. Constructing "double quality" teaching structure is crucial: through social practice, teachers can know well of the real demand for graduates in job market. Colleges should get teaching staff trained professionally, and pay more attention to professionals with high quality and high professional qualification, who with practical work experience know better the practical demand of employer for graduates and can offer better guidance in both curriculum design and practice before graduation as well as the skills of job hunting.

Second, we must constantly improve teacher training system and mechanism to enhance their professional abilities, and deepen their understanding of employment-oriented English teaching. Teachers should update teaching ideas to keep the same pace with social changes. Colleges should help teachers to improve themselves by encouraging them to take part in vocational training, lecture and meetings. At the same time, according to the real need of practical teaching, colleges should adopt more ways to strengthen the construction of faculty, for example, outsourcing the employment guidance by hiring talents familiar with outsourcing industry, which can cover the shortage of instructors.

6. To formulate dynamic occupational evaluation system. The employability of students will be regarded as one of main factors to evaluate the professional competence of teachers, and different training measures will be taken according to the employment rate of students, which can greatly help teachers improve the motivation for setting up the new employment-oriented college English teaching mode and for helping students make a better career planning.

\section{The Results}

1. Date processing

The data of this research has been statistically analyzed by applying One-Way ANOVA to analyzing the characters of data (such as mean difference, standard deviations, and the distribution of the test score), and the two-two comparison has been conducted among means by SNK-q. The significance test was 0.05 .

2. The results of the theoretical tests

Students were theoretically tested with test papers in Jining Medical University. The numbers of students in the tables are that of students who took part in the test each time. Form Table II and Table III, we can see that there is no obvious difference between two theoretical tests in the case of the reliability, difficulty and discrimination of the test; From the tables, we can see a remarkable improvement in terms of the over pass rate and excellent rate, but the differences in theoretical test results among two groups are significant $(\mathrm{P}=0.0000<0.01)$. From Table II and Table III, it can be easily seen that at the beginning of the first term when they didn't start their college English learning there is hardly a difference before two groups: Nearly one fifth people failed the exam, few with high marks, with negative skewers distribution and low level in whole. However, when the author changed the traditional teaching mode into the employment-oriented teaching mode in the experimental group, The improvement of the finals results of students in experimental group is marvelous with a significant different $(\mathrm{P}=0.0000<0.01)$. While in the control group which is educated in the traditional teaching mode, more students failed exams, fewer students with high marks because they just lost the enthusiasm for English learning when it is not oriented to their employment. The details can be seen from Table II and Table III.

TABLE II.

CONTRAST BETwEEN THE ENGLISH TEST RESUlts OF THE EXPERIMENTAL GROUP AND THE CONTROL GROUP AT THE BEGINNING OF THE FIRST TERM

\begin{tabular}{|c|c|c|c|c|c|c|c|c|c|c|c|c|c|}
\hline \multirow{2}{*}{ group } & \multirow{2}{*}{$\mathrm{n}$} & \multicolumn{2}{|c|}{$<60$} & \multicolumn{2}{|c|}{$60 \sim 69$} & \multicolumn{2}{|c|}{$70 \sim 79$} & \multicolumn{2}{|c|}{$80 \sim 89$} & \multicolumn{2}{|c|}{$90 \sim 100$} & \multirow{2}{*}{$Z$} & \multirow{2}{*}{$P$} \\
\hline & & $\mathrm{n}$ & $\%$ & $\mathrm{n}$ & $\%$ & $\mathrm{n}$ & $\%$ & $\mathrm{n}$ & $\%$ & $\mathrm{n}$ & $\%$ & & \\
\hline 实验组 & & 17 & 17 & 39 & 40 & 29 & 30 & 11 & 11 & 2 & 2 & & \\
\hline 对照组 & & 15 & 15 & 38 & 39 & 30 & 31 & 13 & 13 & 1 & 1 & 0.400 & 0.689 \\
\hline 合计 & & 32 & 16 & 77 & 40 & 59 & 30 & 24 & 12 & 3 & 2 & & \\
\hline
\end{tabular}

TABLE III.

CONTRAST BETWEEN THE ENGLISH TEST RESUlTS OF THE EXPERIMENTAL GROUP AND THE CONTROL GROUP AT THE END OF THE FOURTH TERM

\begin{tabular}{|c|c|c|c|c|c|c|c|c|c|c|c|c|c|}
\hline \multirow{2}{*}{ group } & \multirow{2}{*}{$\mathrm{n}$} & \multicolumn{2}{|c|}{$<60$} & \multicolumn{2}{|c|}{$60 \sim 69$} & \multicolumn{2}{|c|}{$70 \sim 79$} & \multicolumn{2}{|c|}{$80 \sim 89$} & \multicolumn{2}{|c|}{$90 \sim 100$} & \multirow{2}{*}{$Z$} & \multirow{2}{*}{$P$} \\
\hline & & $\mathrm{n}$ & $\%$ & $\mathrm{n}$ & $\%$ & $\mathrm{n}$ & $\%$ & $\mathrm{n}$ & $\%$ & $\mathrm{n}$ & $\%$ & & \\
\hline 实验组 & & 6 & 6 & 21 & 21 & 33 & 34 & 29 & 30 & 9 & 9 & & \\
\hline 对照组 & & 21 & 22 & 54 & 56 & 18 & 18 & 3 & 3 & 1 & 1 & 7.149 & 0.000 \\
\hline 合计 & & 27 & 14 & 75 & 39 & 51 & 26 & 32 & 16 & 10 & 5 & & \\
\hline
\end{tabular}

3. The analysis of the follow-up survey

The author of this essay has accumulated some data about the learning input through the observation in class and the interviews after class. The learning input consists of time engagement and emotional engagement (LV You, 2019). The results have been illustrated in Table IV. From the line chart, we can see that there was growing enthusiasm for English learning and almost peaked at the end of the second semester, because there is a nationwide English test, CET 4 (College English Test Band Four), which every undergraduate has to pass to get a bachelor degree. So the first two semesters, most students learn English mainly due to the task of passing CET 4. But we can see a big difference after that: There is an obvious sharp downturn in the passion of students for English learning in control group, the reason of which is that the traditional teaching method focusing the basic knowledge can't help students having passed CET4 in job hunting, so they considered English learning to be useless and the passion for English learning disappear promptly after they passed CET4; while there is a little decline in enthusiasm for English learning in experimental group which is 
still higher than that in control group, mainly because students wanted a break after two semesters' hard working for CET 4, and we can see that from the end of the third semester students' enthusiasm for learning keep growing, even higher than that of the end of the second semester, which is mainly due to the fact that the employment-oriented teaching method can help students make a better career plan and become competitive in job hunting. It's easily concluded that there is hardly a difference in test-oriented education between the tradition teaching mode and the employment-oriented teaching mode; while when it comes to the capability to meet the social demand, the employ-oriented teaching mode is significantly superior to the traditional one.

TABLE IV

CONTRAST BETWEEN THE CONTROL GROUP AND THE EXPERIMENTAL GROUP IN LEARNING INPUT

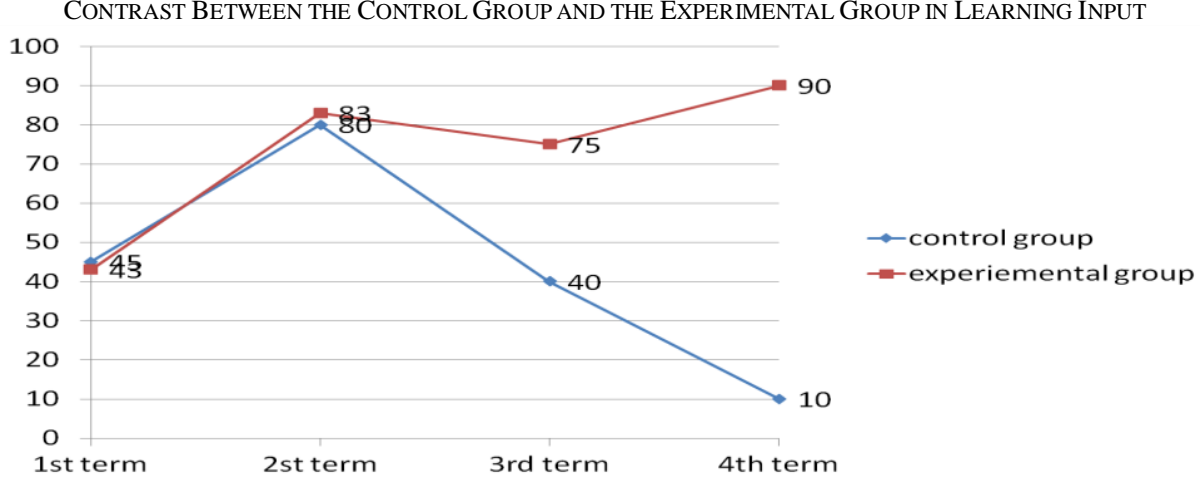

\section{DISCUSSION}

From the final results of theoretical tests and the analysis of the follow-up survey, it can be easily seen that employment-oriented teaching mode is the one that can meet the social demand for inter-disciplinary talents to the greatest extent. The teaching goal can be achieved due to the characteristics of the employment-oriented college English teaching mode

1. It's more flexible to set up professional curriculums. As a result of the rapid economic development, there is a growing demand for compound qualified talents, so when setting up professional curriculums, not only do universities and colleges need to help students master the basic knowledge from book, but also make the curriculums diverse and promote interdisciplinary study to help students broaden their horizons and improve students' comprehensive application of their knowledge. Thus, in college English teaching, teachers should offer different curriculums and different teaching plans according to the professional demand for English of different majors, so that students can practically improve their English proficiency.

It pays much attention to improve students' job competence. To students, their job competence will be illustrated not only through their expertise and their practical abilities but also through their abilities of communicating and cooperating in team work as well as their individual psychological diathesis. Therefore, only when college English teaching mode is employment-oriented and only when teachers attach more importance to the improvement of students' comprehensive abilities, can students be more competent in job hunting (OU Ying and Jiang Mei, 2014).

2. The Significance of the Employment-Oriented College English Teaching Mode

In teaching practice, the employment-oriented college English teaching mode has shown its significance in promoting the development of students and universities, and in maintaining social stability.

a. The employment-oriented teaching mode can help students to gain their self-value. Being employed after graduation is the first step for students to prove and gain their self-value while the employment-oriented teaching mode makes it possible.

b. The employment-oriented teaching mode can help universities gain sustainable development. As more and more graduates have poured into job market, it's become harder for them to be employed. Under this circumstance, the employment rate has become an important factor to foresee a university's prospect. So the employment-oriented teaching mode can help students improve their professional quality and make them more competitive in job hunting, which can help universities survive the competition and gain themselves a bright future.

c. The employment-oriented teaching mode is good for social stability. The employment of graduates is a big issue now, so it will attach a great importance to market optimization and social stability if we can help undergraduates make a clear career plan to maximize their possibility of getting employed.

\section{CONCLUSION}

The main social function of universities and colleges is to train qualified graduates to meet social demands for applied talents based on the present social development. When it comes to undergraduate education, educational courses should be carried out to improve pertinence and effectiveness of talents cultivation, and aim at training all-round talents for all walks of life. Oriented to employment, universities should combine students' majors with job skills. The 
increasingly demand of our society for high level and practical talents urge people to put employment-oriented teaching mode on the agenda. Practically, applicative undergraduate education is the education oriented to employment, thus, the so-called "order cultivation pattern" is exactly the one with employment orientation. This kind of new teaching mode has virtually narrowed the gap between teaching and employment, kind of industry-university cooperation. By combining theoretical learning and practical operating together, featuring its flexibility and practicality, the employment-oriented teaching mode will make the goals of education closer to the demands of jobs.

\section{REFERENCES}

[1] Cai Hong. (2019). Study on the Correlation Between Learning Motivation and Achievement of Non-English Majors. New West. Vol.21, 50-51.

[2] Juan Du. (2017.) On the Application of Situational Language Teaching Method to Mongolian English Majors. English Language and Literature Studie. Vol. 7, 98-103.

[3] Liao Youguo. (2011). The Compilation of College Students' Learning Engagement Questionnaire and the Investigation of Current Situation. Journal of Jimei University. Vol.2, 39-44.

[4] Luo Huan.(2013). The Necessity of Offering Medical English Courses in Medical Colleges and Universities. Overseas English. Vol.16, 39-40.

[5] LV You. (2019). A Review of the Research on the Control Strategies of Motivation in English Learning in China. Modern Communication. Vol.22, 215-216.

[6] OU Ying and Jiang Mei. (2014). A comparative Study on the Training Mode of Compound English Majors. Overseas English. Vol.22, 1-2.

[7] Shu Na. (2016). Vocational English Curriculum Design Based on Employment-Oriented Cooperative Teaching Model. Course Education Research. Vol.10, 120-121.

Yuefang Sun, born in Jining, Shandong Province in 1979. She received the bachelor degree from Shandong Science and Technology University in 2002, and the master degree from Qufu Normal University in 2012.

She is currently a lecturer in School of Foreign Languages, Jining Medical University, Jining, China. She has been teaching in Jining Medical University for seventeen years; courses taught include Integrated English, and Traditional Chinese Cultures (English version). Her research interests include Applied Linguistics and second language acquisition. 